\title{
EVALUATION OF THE ROLE OF ANTIOXIDANT IN AGE-RELATED CATARACT
} PATIENTS

\author{
Mohammed Abou El-Fetouh Ramadan (1), Lubna Y. Ibraheem ph.D ${ }^{(2)}$ \\ (1) Department of Ophthalmology, Benha Teaching Hospital, (2) Department of clinical pathology, Benha, \\ Teaching Hospital
}

ABSTRACT
Purpose: to assess the role of oxidative stress as a risk factor and antioxidant enzymes as a protection factor
against age related cataract.
Methods: in a prospective study 20 patients with senile cataract and 10 control subjects were selected and
matched. The levels of glutathione peroxidase (GPx) enzyme and catalase enzyme were measured in
erythrocytes, and total antioxidants were measured in plasma. All results were compared by student's "t" test
and Chi-square analysis $(\mathrm{P}<0.05$ for significance).
Results: the levels of erythrocyte GPx activity in patients and control group were found a mean value of
$108.96 \pm 32.46 \mathrm{mu} / \mathrm{ml}$ and $194.68 \pm 8.74 \mathrm{mu} / \mathrm{ml}$, respectively $(\mathrm{P}<0.01)$ highly significant. Catalase level was
$0.111 \pm 0.033 \mathrm{u} / \mathrm{ml}$ in patients and $0.118 \pm 0.037 \mathrm{u} / \mathrm{ml}$ in control group which was statistically non-
significant $(\mathrm{P}>0.05)$. Total antioxidant levels of patient and controls were $0.99 \pm 0.243 \mathrm{mM} / \mathrm{L}$ and
$1.088 \pm 0.283 \mathrm{mM} / \mathrm{L}$, respectively $(\mathrm{P}>0.05)$ non-significant.
Conclusion: The role of antioxidant enzymes in the protection against senile cataract formation is still
controversial. As the result of this study, glutathione peroxidase enzyme is found to be the most important
enzyme over the other antioxidants as a strong correlation was found between the low levels of GPx in
erythrocytes and the development of senile cataract. However large multi-center studies are required before
establish this concept.
Keywords: Oxidative stress, senile cataract, glutathione peroxidase, catalase total antioxidant

Keywords: Oxidative stress, senile cataract, glutathione peroxidase, catalase, total antioxidant.

\section{INTRODUCTION}

$I^{\prime}$ $\mathrm{t}$ is though that osmotic stress and exogenous or endogenous oxidative stress play an important role in the pathogenesis of cataract as the lens proteins are subjected to extensive oxidative modifications. ${ }^{\mathbf{1 , 2}}$

Oxidative stress may results from an imbalance between the production of reactive oxygen species (ROS) and the cellular antioxidant defence mechanisms. In the cells of the eye ROS may initiate a surge of toxic biochemical reaction such as peroxidation of membrane lipids and extensive damage to proteins causing intracellular protein aggregation and precipitation resulting in senile cataract formation. ${ }^{3,4}$

The human body has a variety of natural antioxidants, which help to protect against oxidative insult. These systems scavenge free radicals and prevent oxidative damage. They include intracellular (enzymatic) antioxidants such as the enzyme superoxide dismutase (SOD), catalase, glutathione peroxidase (GPx) and total antioxidant (non-enzymatic) like vitamin $\mathrm{E}$, vitamin $\mathrm{C}$ and beta carotene. ${ }^{\mathbf{5} 6}$ The synthetic antioxidants like vitamins, minerals and enzymes when taken in low dose supplementation is able to normalize the biological nutrients status and improve the antioxidant defence parameters in elderly subjects against free radicals ${ }^{7}$. The aim of this study was to determine the levels of total antioxidant and the activity of erythrocyte GPx and catalase in Egyptian patients with senile cataract.

\section{PATIENTS AND METHODS}

In a prospective study conducted from January 2009 to December 2009 in Ophthalmology Department of Benha Teaching Hospital. The study was performed on the blood samples obtained from 20 patients diagnosed as having mature senile cataract and 10 control subjects. Information was obtained about smoking habits, diseases such as diabetes and hypertension, use of medication and occupational background. Thorough and complete ophthalmic examination was done for all subjects. The sex distribution in the patients and control group was $70 \%$ females and $30 \%$ males

\section{Exclusion Criteria:}

All subjects in both groups have no local or systemic diseases including diabetes or hypertension.

\section{Blood collection and sampling:}

The laboratory tests included the followings:

A fresh heparinized blood sample $(3 \mathrm{ml})$ was drawn from each patients and controls and then centrifuged at 4000 r.p.m. for 5 minutes at $4 \mathrm{C}^{\circ}$. The plasma was collected and stored in freeze at$80 \mathrm{C}^{0}$ for assaying catalase and total antioxidant. The red cell pellets was washed by cold buffer and lysed by cold de-ionized water and centrifuged at 4000 r.p.m. for 5 minutes and the resulting clarified supernatant was collected and stored at $-80 \mathrm{C}^{0}$ for assaying erythrocytes glutathione peroxidase.

Catalase was determined calorimetrically according to the method of Aebi. ${ }^{\mathbf{8}}$ The catalase 
react with a known quantity of $\mathrm{H} 2 \mathrm{O} 2$ and the reaction is stopped after exactly one minute with catalase inhibitor. In the presence of peroxidase (HRP), remaining $\mathrm{H} 2 \mathrm{O} 2$ reacts with 3,5-dichloro2-hydorxybenzen sulfonic acid (DHBS) and 4aminophenazone (AAP) to form a chromophore with color intensity inversely proportional to the amount of catalase in original sample.

The determination of total antioxidant concentration was performed calorimetrically according to the method of Koracevic. ' The reaction of antioxidant in the sample with a defined amount of exogenously provided hydrogen peroxidase ( $\mathrm{H} 2 \mathrm{O} 2)$. The antioxidant in the sample eliminate a certain amount of the provided $\mathrm{H} 2 \mathrm{O} 2$. The residual $\mathrm{H} 2 \mathrm{O} 2$ is determined calorimetrically by an enzymatic reaction which evolves the conversion of 3.5 , dichloro-2-hydroxybenzensulphonate to a coloured product.

Erythrocytes glutathione peroxide was measured by colorimetric method reported by a Paglia and Valentine $^{\mathbf{1 0}}$. GPx catalyze the oxidation of the glutathione by cumene hydorperoxide. In the presence of glutathione reductase and NADPH, the oxidized glutathione is immediately converted to the reduced form with a concomitant oxidation of NADPH to NADP.

\begin{tabular}{|c|c|c|c|c|}
\hline Parameter & Patients $(n=20)$ & Control $(n=10)$ & t-test & $\mathbf{P}$ \\
\hline Age (year) & $60.2 \pm 8.19$ & $57.9 \pm 10.96$ & 0.848 & $>0.05$ \\
\hline $\begin{array}{l}\text { glutathion peroxides } \\
(\mathrm{mu} / \mathrm{mL})\end{array}$ & $108.96 \pm 32.46$ & $194.68 \pm 8.74$ & 66.47 & $<0.01$ \\
\hline catalase $(\mathrm{U} / \mathrm{mL})$ & $0.111 \pm 0.033$ & $0.118 \pm 0.037$ & 0.6107 & $>0.05$ \\
\hline Total antioxidase (mM/L) & $0.99 \pm 0.243$ & $1.088 \pm 0.283$ & 0.177 & $>0.05$ \\
\hline
\end{tabular}

\section{DISCUSSION}

Oxidative stress may be risk factor in senile cataract which causes loss in lens transparency and impairment of protein metabolism in the course of this degenerative disease. Assays of the erythrocytes and plasma antioxidant activities could provide a marker to identify individuals predisposed to senile cataract. ${ }^{11}$ In the antioxidant defence mechanisms, glutathione peroxidase provide the necessary balance to offset the oxidant effect. The biologically function of GPx is to reduce lipid hydroperoxidase to their corresponding alcohols and reduce the free hydrogen peroxide $[\mathrm{H} 2 \mathrm{O} 2]$ to water $[\mathrm{H} 2 \mathrm{O}] .^{\mathbf{1 2}}$ Catalase is an enzyme which is present in most cells and catalyses the decompositions of $\mathrm{H} 2 \mathrm{O} 2$ to
Statistical analysis was done suing student's " $t$ " test and chi-square analysis methods; $\mathrm{P}<0.05$ was considered as statistically significant.

\section{RESULTS}

The results are summarized in table (1). Mean age $( \pm \mathrm{SD})$ of patients and control were $60.2 \pm 8.19$ and $57.9 \pm 10.96$, respectively $(\mathrm{P}>0.05)$ showing no significant difference.

Evaluation of mean erythrocytes GPx activity for both groups indicated a mean value of $108.96+32.46 \mathrm{mu} / \mathrm{ml}$ for patients and $194 \pm 8.74$ $\mathrm{mu} / \mathrm{ml}$ for control $(\mathrm{P}<0.01)$ highly significant difference. Erythrocyte activity of catalase patients and controls was found to be $0.111 \pm$ $0.033 \mathrm{u} / \mathrm{ml}$ and $0.118 \pm 0.037 \mathrm{U} / \mathrm{ml}$, respectively ( $\mathrm{P}>0.05)$ non-significant difference. Total antioxidant level in the plasma was $0.99 \pm 0.243$ $\mathrm{mM} / \mathrm{L}$ in patients and $1.088 \pm 0.288 \mathrm{mM} / \mathrm{L}$ in controls $(\mathrm{P}>0.05)$ indicating non-significant difference between patients and control group. The data were recorded and statistically analyzed using standard student "t" tests, Chi square and descriptive statistics, $\mathrm{P}$ was considered significant if $<0.05$.

Table (1): comparison of the mean age, glutathione peroxidase, catalase and total antioxidant in patients and control group 
In this study, evaluation of erythrocyte GPx shows lower level in the patients group than control group and was statistically highly significant $(\mathrm{P}<0.01)$, so the decrease of the level of GPx in erythrocytes is considered a major risk factor in the process of senile cataract formation. In our study; the reason of the lowering level of erythrocytes GPx in patients group may be due to more production of ROS.

Our results agree with Donma et al. ${ }^{11}$ who found that the whole blood glutathione value was significantly lowered in cataract patients than these of control group and they stated that the high concentrations of GPx associated with lower risk of senile cataract formation. The role of erythrocytic GPx enzyme as a protective factor against cataract formation is confirmed by Girodon et al. ${ }^{7}$ who reported that erythrocyte GPx activity was enhanced in elderly subjects receiving minerals and vitamins in low doses for two years supplementation, which results in increase the antioxidant defence mechanisms against free radicals and decrease the incidence of cataract formation.

Some change was found by Ghandrasena et al. ${ }^{\mathbf{1 6}}$ who reported that there was no significant difference in GPx activity between the cataract and non-cataract groups.

Against our results, Issa et al. ${ }^{17}$ found that the level of GPx erythocytic activity in the patients group was increased than control group with significant differences. They considered the rise in the activity of GPx to be a landmark for cataract formation in patients group and this result considered against the results of the most previous and recent studies.

In our study the catalase levels in the erythrocyte were low in the patients group but not statistically significant difference $(\mathrm{P}>0.05)$.

Our results confirmed by Pradhan et al. ${ }^{18}$ who found that erythrocytic catalase levels were decreased in cataract group when correlated with control group but the difference was not statistically significant. But Ghandrasena et al. ${ }^{16}$ found that there was a significant lower levels of catalase activities in the patients with senile cataract when compared with non-cataract patients.

From the results of our study and most of previous studies rising the concept that the decreased level of erythrocytic catalase enzyme does not play a significant role in the process of senile cataract formation.

The levels of plasma non enzymatic total antioxidants (vitamin $\mathrm{E}$, vitamin $\mathrm{C}$ and $\beta$ carotene) were in this study, more in control group than in patients group with no significant difference $\mathrm{P}>0.05$.

Our study shows non-significant decreased levels of plasma total antioxidants in cataract group may be due to their utilization by counteracting ROS. Our results confirmed by Issa et al. ${ }^{17}$ who reported that the total antioxidant values were lower in patients group with no significant different. Pradhan et al. ${ }^{18}$ found that vitamin $\mathrm{C}$ levels is the plasma significantly lower in cases of cataract and vitamin E level were marginally lowered in group of cataract patients. They also reported that the $\beta$ carotene levels in plasma were significantly decreased in all types of age related cataract group when compared with control group, on the other side Vitale et al. ${ }^{19}$ and Soars et al. ${ }^{20}$ found that the higher level of plasma total antioxidants were not associated with risk of senile cataract.

\section{CONCLUSION}

The role of antioxidant enzymes in the protection against senile cataract formation is still controversial. As the results of this study, glutathione peroxidase enzyme is found to be the most important enzyme over the other antioxidants as a strong correlation was found between the low levels of GPx in erythrocytes and the development of senile cataract. However large multi-center studies are required before establish this concept.

\section{REFERENCES}

1. Halliwell B. Antioxidant: The basic - what they are and how to evaluate them. Adv Pharmac, 1997; 38: 3-19.

2. Casado A, de La Torre R, Lopez-Femanado E. Antioxidant enzyme levels in red blood cells from cataract patients. Gerontology, 2001; 47 (4): 186- 8.

3. Micilli-Ferrari T, Vendemiale G, Grattoglione et al. Role of lipid peroxidation in the pathogenesis of myopic and senile cataract. $\mathrm{Br}$ J Ophthalmol, 1996; 80: 840 - 3.

4. DeHaan JB, Cristiano F, Jannello RC, Kola Culzu. Superoxide dismutase and glutathione peroxidase during aging. Biochem Mol Biol, 1993; 35: 1281.

5. Rumely AG, Paterson JR. Analytical aspect of antioxidants and free radical activity in clinical biochemistry. Am Clin Biochem, 1998; 35: $181-200$.

6. West SD. Who develops cataract? Ach Ophthalmol, 1991; 104: 196-8.

7. Girodon F, Blache D, Monget AL, Lombart M. Effect of a two-year supplementation with low doses of antioxidant vitamins and/or minerals in elderly subjects on levels of nutrients and 
antioxidant defence parameters. J Am Coll Nutr, 1997; 16 (4): 357 -65.

8. Aebi H. Catalase In: Packer(Ed), methods in enzymology, Academic press, Orlando, 1984; 105: 121-6.

9. Koracevic D, Koracevic G, Jordjevic VD. Method for the measurement of antioxidant activity in human fluids. J Clin Pathol., 2001; 54: 356-61.

10. Paglia DE, Valentine WN. Studies on the quantitative and qualitative characterization of erythrocyte glutathione peroxidase. J Lab Clin Meth, 1967; 70: 158-69.

11. Donma O, Yorulmaz E, Pekel H, Suyugul N. Blood and lens lipid peroxidation and antioxidant status in normal individual, senile and diabetic cataractous patients. Curr Eye Res, 2002; 25 (1): 9 -16.

12. Ran Q, Liang H, Ikeno Y, Qi W, Prolla TA, Roberts LJ 2nd, Wolf N, Van Remmen H, Richardson A. Reduction in glutathione peroxidase 4 increases life span through increased sensitivity to apoptosis. J Gerontol A Biol Sci Med Sci, 2007; 62(9):932-42.

13. Bhuyan KC and Bhuyan DK. Superoxide dismutase of the eye. Relative functions of superoxide dismutase and catalase in protecting the ocular lens from oxidative damage B.B.A. 1978; 542,28-38.

14. Gale CR, Hall NF, Phillips DI, Martyn CN. Plasma antioxidant vitamins and carotenoids and age- related cataract. Ophthalmology, 2001; 108 (11): 1992-8.

15. Simon JA, Hudes ES. Serum ascorbic acid and other correlation of self - reported cataract among older Americans. J Clin Epidemiol Des, 1999; 52 (12): 1207.

16. Ghandrasena LG, Chack vewarthy S, Perera PT. Erythrocyte antioxidant enzymes in patients with cataract. Ann Clin Lab Sci Spring, 2006; 36 (2): 201.

17. Issa N, Ladan G, Mehdi M. Evaluation of erythrocyte glutathione peroxidase, superoxide dismutase and total antioxidants in cataract patients. Archives of Iranian Medicine, 2001; (3): 123-6.

18. Pradhan AK, Shukla AK, Reddy MR, et al. Assessment of oxidative stress and antioxidant status in age related cataract in a rural population. Indian J Clin Biochem., 2004; 19 (1) $83-7$.

19. Vitale S, West S, Hallfrisch J, Alston C. Plasma antioxidants and risk of cortical and nuclear cataract. Epidemiology, 1993; 4(3): 195-203.

20. Soars FM, Noqueira NdoN, Marreiro DdoN, Carvalho CM. Plasma and erythrocyte zinc concentrations in elderly patients with and without senile cataract in arteria eye care center at Teresina-pain. Age Brase Ophthamol, 200871 (5): 674-8 